\title{
Public Regulators and CSR
}

The 'Social Licence to Operate' in Recent United Nations Instruments on Business and Human Rights and the Juridification of CSR

Buhmann, Karin

Document Version

Accepted author manuscript

Published in:

Journal of Business Ethics

DOI:

$10.1007 / \mathrm{s} 10551-015-2869-9$

Publication date:

2016

License

Unspecified

Citation for published version (APA):

Buhmann, K. (2016). Public Regulators and CSR: The 'Social Licence to Operate' in Recent United Nations Instruments on Business and Human Rights and the Juridification of CSR. Journal of Business Ethics, 136(4), 699-714. https://doi.org/10.1007/s10551-015-2869-9

Link to publication in CBS Research Portal

\section{General rights}

Copyright and moral rights for the publications made accessible in the public portal are retained by the authors and/or other copyright owners and it is a condition of accessing publications that users recognise and abide by the legal requirements associated with these rights.

\section{Take down policy}

If you believe that this document breaches copyright please contact us (research.lib@cbs.dk) providing details, and we will remove access to the work immediately and investigate your claim. 


\title{
Public Regulators and CSR: The 'Social Licence to Operate' in Recent United Nations Instruments on Business and Human Rights and the Juridification of CSR
}

\section{Karin Buhmann}

Journal article (Accepted version)

\begin{abstract}
CITE: Public Regulators and CSR: The 'Social Licence to Operate' in Recent United Nations Instruments on Business and Human Rights and the Juridification of CSR. / Buhmann, Karin. In: Journal of Business Ethics, Vol. 136, No. 4, 2016, p. 699-714.
\end{abstract}

This is a post-peer-review, pre-copyedit version of an article published in Journal of Business Ethics. The final authenticated version is available online at: https://doi.org/10.1007/s10551-015-2869-9

Uploaded to Research@CBS: Mlay २०18 
Published in the Journal of Business Ethics DOI 10.1007/s10551-015-2869-9

Public regulators and CSR: The 'Social Licence to Operate' in recent United Nations
instruments on Business and Human Rights and the juridification of CSR

Karin Buhmann ${ }^{1}$

\begin{abstract}
The social licence to operate (SLO) concept is little developed in the academic literature so far. Deployment of the term was made by the United National (UN) Guiding Principles on Business and Human Rights and the UN 'Protect, Respect and Remedy' Framework, which apply SLO as an argument for responsible business conduct, connecting to social expectations and bridging to public regulation. This UN guidance has had a significant bearing on how public regulators seek to influence business conduct beyond Human Rights to broader Corporate Social Responsibility (CSR) concerns. Drawing on examples of such public regulatory governance, this article explores and explains developments towards a juridification of CSR entailing efforts by public regulators to reach beyond jurisdictional and territorial limitations of conventional public law to address adverse effects of transnational economic activity. Through analysis of an expansion of law into the normative framing of what constitutes responsible business conduct, we demonstrate a process of juridification entailing a legal framing of social expectations of companies, a proliferation of law into the field of business ethics, and an increased regulation by law of social actors or processes.
\end{abstract}

\title{
1. Introduction
}

Evolving in the extractives field as an issue of considerable practical relevance to business operations (Prno \& Slocombe 2012, Owen \& Kemp 2013; Burke et al. 2011, Nelken 2006), the 'social licence to operate' (SLO) concept has spread to CSR practices and theory more generally. A clear example is offered by two recent instruments that provide guidance for both firms and states as regards business and human rights: the UN Guiding Principles ('UNGP') on Business and Human Rights (UN 2011) and their predecessor, the 2008 UN 'Protect, Respect and Remedy' Framework (UN 2008). Both instruments as well as background documents apply the SLO concept to create appreciation of the economic and societal costs associated with business related human rights abuse. In the context they connect social expectations, business self-regulation, and governmental soft and hard law. ${ }^{2}$ SLO and public regulation of CSR may appear distinct. However, the articulation of SLO was part of the discursive process that led to adoption of the soft law UNGP and UN Framework (Buhmann 2014), in turn spurring revisions, development and adaptation of more detailed public soft and hard law relating not only to 'business and human rights' but to CSR in a broader sense. Revisions to the Organisation of Economic Cooperation and Development (OECD) Guidelines for Multinational Enterprises (OECD 2011), the EU's 2011 Communication on CSR (EU 2011) and well as national level CSR reporting requirements testify to this. The UN Global Compact Principles on Human Rights link to the UNGP, and elements of ISO's 26000

\footnotetext{
${ }^{1}$ Karin Buhmann, Dr.Scient.Adm .\& PhD, e-mail kbu.ikl@cbs.dk; buhmann@ ruc.dk.. While writing this article the author has been employed at the Department of Intercultural Communication and Management, Copenhagen Business School, Porcelænshaven 18, 2000 Frederiksberg, Denmark; and the Department of Communication, Business and IT, Roskilde University, Universitetsvej 1, 4000 Roskilde, Denmark.

2 This article employs 'soft law' and 'hard law' in accordance with international law terminology. 'Soft law' refers to non-binding measures, 'hard law' to binding measures. Thus, private binding regulation - like a contract - is hard. Nonbinding public measures - like the Guiding Principles - are soft.
} 
Social Responsibility Guidance Standard were influenced by the UNGP. Inspired by the UNGP, a proposal for a binding international treaty on business and human rights has been proposed for UN debate. This forms part of what we discuss as a juridification of CSR, meaning that CSR is increasingly being subject to public regulation through hard, soft and mixed forms of law.

An emergent literature recognises the increasing public role in 'political CSR' (Scherer \& Palazzo 2007, 2011) but also struggles with what to make of this (e.g., Scherer and Palazzo 2011, Wheelan, Moon and Orlitzky 2009, Matten and Moon 2008, Haufler 2001). As probably unintentionally exemplified by Knudsen \& Brown (2014), the complex human rights issues that require or motivate much public regulation of CSR remain poorly understood (compare Ruggie 2013). Within the context of this Special Issue, the adoption of the SLO concept by the UN Framework and UNGP and their subsequent influence on public initiatives to shape CSR offer a basis for discussing not only why but also how public regulators increasingly regulate CSR.

Among CSR instruments, the UN Framework and UNGP are unique in being developed under the UN. The world's largest international organisation and governed by the UN Charter from 1945, the UN normally regulates states' conduct through soft (non-binding) or hard (legally binding) law. Adopted by the UN Human Rights Council in 2011, the UNGP were drafted by Professor John Ruggie under a special UN mandate on Business and Human Rights, as was the UN Framework. Thus, importantly, the UNGP and Framework (despite sometimes referenced the 'Ruggie Principles' and 'Ruggie Framework') were developed as UN instruments. This puts them apart from the range of private CSR guidance instruments or certification schemes, such as SA8000, Fair Labour Association (FLA), the Forest Stewardship Council (FSC) or the Marine Stewardship Council (MSC)). It also differentiates them from public-private initiatives such as the Voluntary Principles on Business and Human Rights or the Kimberley Process, that have been agreed to between a limited number of involved governments and the sectoral industry (oil/gas and diamonds, respectively). In addressing both businesses and states explicitly and emphasising both legal compliance and voluntary respect based on social expectations, the UN Framework and UNGP also differ from the UN Global Compact, comprising purely voluntary principles for business. Indeed, at the backdrop of previous failures, the UN Framework and UNGP were ground-breaking in leading to agreement on UN guidance on business and human rights (De Schutter 2013). These differences in themselves warrant a discussion of a juridification of CSR. The role the instruments award to SLO underscore the relevance in the business ethics context to promote public policy objectives related to a particular CSR field, i.e., human rights. That is further underscored by their influence on other public regulatory CSR initiatives beyond human rights.

In the business ethics and organisational literature the UNGP and UN Framework have so far been addressed mainly from two angles: A philosophical-normative approach, stressing coherence with ethical foundations related to human rights (e.g., Fasterling and Demuinck 2013, Cragg 2012, Arnold 2010, Wettstein 2009); and a dogmatic-legal approach, focusing on the implications in terms of standards of conduct for business (e.g., Muchlinski 2012, Bernaz 2012, McCorquedale 2009). The novelty of the emergence of public regulation on business responsibilities for human rights has received less attention, as has the impact on broader CSR regulation and normativity. The modalities of such regulation and their background in a regulatory vacuum caused by the limitations of conventional international and national public law so far have not been addressed in this literature. 
We contribute to remedying these gaps. Taking point of departure in SLO application in the UN instruments and their basis in the UN's policy objectives of promoting human rights, we explain why governments are increasingly engaging in shaping CSR policies and actions and provide examples of how this is happening. That is done by looking at the influence of the UN instruments on other public regulatory modalities seeking to govern CSR, and discussing these developments against the limitations of conventional public law.

Doing so adds important perspectives on the public regulatory side of political CSR that have been noted by other authors but so far not been explored in detail. This article complements the literature on 'political' CSR (Scherer \& Palazzo 2011) by showing how public law is gaining influence in shaping CSR in diverse ways.

To provide background, section 2 first introduces the UN Framework and the UNGP. Next, it introduces key features of the 2011 revision of OECD's Guidelines, EU's 2011 CSR Communication and CSR reporting requirements, which bear witness to influence from the UN instruments. Section 3 sets out method and deliminations, and section 4 explains the theoretical approach to analysis of why and how public regulators are engaging in shaping CSR. This is grounded in the constraints of public law and novel approaches fitting under transnational regulatory theory. Section 5 offers a literature review, opening with 'juridification', moving on to SLO, and finalising by identifying gaps in the literature as to why and how public regulators engage in CSR regulation. Section 6 discusses the role of the SLO concept in the UN framework and UNGP and its significance for the term as well as public regulation of CSR. Section 7 shows how public regulators are seeking to regulate business conduct: The UN Framework and UNGP (7.1), the 2011 revision of OECD's Guidelines for Multinational Enterprises (7.2), and CSR transparency and mandatory reporting (7.3), with focus on EU and national mandatory CSR reporting influenced by the UN guidance. Section 8 discusses these developments as a juridification of CSR that functions as a transnationalisation of law, informed by the significance of the SLO and expanding the UN guidance on business and human rights to broader CSR regulation. Section 9 concludes.

\section{Background}

\subsection{The UN Framework and UNGP}

The background to the UN Framework and UNGP was a failed effort by a group of international human rights law experts under the UN that culminated with the rejection of the draft UN 'Norms' on business and human rights. Instead, the UN Secretary General appointed Harvard Professor John Ruggie as holder of a special mandate on business and human rights. The mandate referred to Corporate Social Responsibility (CSR) but focused on the issue of business and human rights. This led to the UN Framework, adopted by the UN's Human Rights Council in 2008. The Council issued a second three year mandate asking John Ruggie to 'operationalise' the framework, resulting in in the UNGP.

By contrast to the UN Global Compact, the UN Framework and UNGP are not only based on voluntary commitment by business, but also articulate business compliance and public regulation. The UNGP spell out the normative directives contained in the UN Framework in operational terms for both states and enterprises. 'Pillar One' sets recommendations for public authorities for ensuring business respect for human rights and promoting this through 'smart' regulation, comprising a mixture of incentives, soft guidance and hard law. 'Pillar Two' provides business organisations with detailed guidance for analysing, managing, reducing and remedying adverse impact on human rights. 'Pillar Three' sets guidance for both businesses and states for ensuring access to remedy. 
The UN Framework sets out businesses' responsibility as encompassing respect for all human rights contained in the 'International Bill of Human Rights' (comprising the Universal Declaration of Human Rights, the International Covenant on Civil and Political Rights and the International Covenant on Economic, Social and Cultural Rights) and international core labour rights contained in eight fundamental International Labour Conventions (the freedom of association and collective bargaining; non-discrimination; and elimination of child labour and forced labour).

The UNGP recognise that states have a fundamental duty to protect individuals against human rights violations, not only by the state but also by business. But states may fail in this, and social expectations may go further than states' legal obligations. Connecting to the SLO argument, the corporate responsibility to respect human rights is described as the basic expectation society has of business.

The UNGP apply to all business enterprises, both transnational and others, regardless of their size, sector, location, ownership and structure. Like the UN Framework, they do not create new obligations, but explain the implications of existing human rights law for businesses as well as for states with obligations to regulate and monitor business conduct and enforce such regulation. The UN Framework and UNGP do not have enforcement modalities of their own. They draw on existing enforcement modalities, both legal and market based sanctions related to SLO (author forthcoming).

Like many other CSR instruments, the UN Framework and UNGP are grounded in problems resulting from governance gaps and expectations that businesses step in where public politics and law are ineffective (Backer 2006, Ruggie 2013). Both instruments establish a clear objective to deal with societal problems caused by governance gaps. These result from limitations of international law and policy to address business, and from national governments' inadequate implementation of obligations under international and sometimes national law. Unlike conventional public policy and legal regulation, the two instruments pragmatically sidestep the limitations that conventional public law and policy encounter in terms of regulation of transnational business activity, as elaborated in section 4. Much of this sidestepping was possible due to discursive strategies that bought into particular interests of diverse stakeholders, such as SLO, and explained the implications to other stakeholders (Buhmann 2014). The sidestepping was also due to influence on other public regulatory initiatives, which effectively complement the soft guidance of the UN Framework and UNGP through enforcement, direct regulation of business responsibility for human rights, and promoting transparency (author forthcoming). In a business ethics context this is noteworthy, because the UN instruments led to changes in broader CSR instruments.

\subsection{Influence on other public regulation of CSR}

The OECD, the EU and several national governments are public regulatory organisations which share in the UN's objective of reducing adverse business impact on society. While the UN's main objective is social development and human rights protection, the main aims of EU and OECD are economic growth. Reducing loss of the social licence for the benefit of economic activity are important objectives for these organisations (OECD 2011, EU 2011, Danish Government 2008). Due to their broad support, the UN Framework and UNGP offered a legitimate point of departure for sharpening previous steps by these public regulatory organisations in the CSR field.

OECD's revision of its Guidelines for Multinational Enterprises in 2011 added a chapter on human rights structured in accordance with the UNGP. It developed due diligence requirements for 
business in line with due diligence guidance offered by the UN Framework and UNGP. Importantly these were expanded to apply to most of the CSR-issues covered by OECD's Guidelines. ${ }^{3}$ OECD's Guidelines are recommendations addressed by governments to businesses operating in or from adhering countries. ${ }^{4}$ The territorial scope means that companies may be subject to NCP cases for activities in non-OECD states. The revision also changed procedures for National Contact Points (NCPs) in accordance with the UN Framework. NCPs are complaints handling institutions that states commit to setting up. NCPs have extraterritorial competence in that they may handle complaints of violations of the Guidelines outside the home country of the company that a complaint concerns. Their potential impact on the social licence to operate of transnational companies therefore is considerable.

A soft law instrument developed by an international organisation distinct from the UN, the Guidelines provide non-binding principles for enterprises relating to their economic, social and environmental impact (OECD 2011, Chapter 1). The substantive scope of the Guidelines is broad, covering human rights, labour issues including employment and industrial relations, environment, bribery, disclosure and transparency, consumer interests, science and technology, competition and taxation. Originally developed as an annex to an OECD Declaration on International Investment, the Guidelines remain intended to provide guidance for responsible business conduct in a broader economic context. They aim to address socially adverse transnational economic activity that transgresses national boundaries and therefore conventional regulatory and enforcement powers of home states.

In a 2011 CSR policy document (a 'Communication'), the EU Commission introduced a dramatic change to its CSR definition. Previous definitions had explicitly defined CSR as voluntary business activity beyond legal obligations (EU 2001 paras. 20-21, EU 2002:5). The 2011 definition simply defines CSR as "the responsibility of enterprises for their impacts on society" (EU 2011, section 3.1). Thus, in line with recommendations to authorities in the UN Framework and UNGP, the EU implicitly opened opportunities for public regulation on CSR. With reference to the UN instruments and the revised OECD Guidelines, the Communication referred specifically to the integration of human rights into business management as required by a company.

Influence from the UN instruments is also evident in regulation of CSR transparency and reporting announced in the 2011 Communication. These were inspired by the UNGP call for transparency and 'smart-mix' regulation to stimulate business responsibility and contribute to the preservation of the SLO.

Promoting CSR by providing for transparency through reporting and stimulating business selfregulation was recommended by the UNGP for businesses as well as states. Whereas several countries in Europe (including France, UK, Sweden and the Netherlands) and elsewhere have had mandatory CSR reporting for some years (Ioannou \& Serafeim 2012), mandatory CSR reporting introduced by Denmark in 2008 and revised in 2012 is clearly inspired by the UN Framework and UNGP (Buhmann 2013) and therefore serves as examples in our analysis.

\footnotetext{
${ }^{3}$ The Guiding Principles had been made available in November 2010 in a draft for comments. This draft, which was not substantively altered in the final published in March 2011, had informed the OECD's revision of the Guidelines, which was published in May 2011.

${ }^{4}$ Besides OECD countries, some non-OECD countries, including Argentina, Brazil and Egypt adhere to the Guidelines.
} 
The influence of UN instruments on public regulation of CSR testifies to the significance for business ethics theory and practice. It offers a different perspective from weaknesses that have been noted in the literature regarding the philosophical, organisational and legal-dogmatic foundations or coherence of the instruments (Fasterling and Demuinck 2013, Deva 2013, Cragg 2012, Mares 2012a, Whelan, Moon and Orlitzky 2009). This speaks to the relevance of considering this development for insight on both why public regulators engage in CSR, and how public organisations engage with CSR in efforts to address adverse business impact on society that reduces the SLO.

\section{Method and delimitations}

Because of the increased role that international and national law has for business ethics, particularly in the field of business and human rights, legal theory, method and concepts have proven expedient (compare Bernaz 2012, Muchlinski 2012, Wood 2012, Voiculescu 2011, McCorquedale 2009, McBarnet 2008, Hess 2008). The study of legislative history is applied in international law (Cassese 2005) as well as in EU, some national and transnational law contexts (Zahle 1999, Evald 2005). The method entails a reading of legal texts (such as the UNGP), policy documents and other normative texts in order to gauge the impact and intertextuality (Kennedy 1987). Applied in here, in line with common practice we apply this as a stand-alone method. For future research, interviews and company reporting data may add further perspective.

We adopt public law and transnational regulatory theory as a lens through which to observe and explain the difficulties in regulating transnational business conduct through conventional public law and the emergence of novel regulatory approaches. Thus, we do not test theory to seek to answer whether transnational law offers solutions to global governance problems, but apply it to provide a theory based background for emerging developments entailing regulation to address global concerns, often by combining public and private regulation in novel forms and processes of interaction. Given the novelty of academic treatment of the juridification of CSR and SLO in that context, this article limits its focus. Both effectiveness of transnational law and business responses are fascinating and complex issues to put the juridification into perspective. Such analysis is best undertaken in a few years' time when we may observe trends in responses to the UN guidance and impact on other public regulation. ${ }^{5}$

We observe how the UN instruments adopted the SLO concept that added to the influence of the UN Framework and UNGP on regulatory initiatives at three different levels of public governance to address business ethics through regulating CSR: OECD's Guidelines, EU's 2011 Communication and CSR transparency and reporting requirements proposed for EU and Danish companies. Based on our analysis we explain transnational public regulation of business emerging as a response to the limitations of conventional public law as regards socially responsible business activity, resulting in juridification of CSR.

\section{Theoretical approach}

\subsection{Public law: constraints for regulating social impact of transnational economic activity}

The conventional system of international law is state-centered and gives only limited role to business organisations (being non-state actors). Going beyond these limitations has required innovative approaches by intergovernmental organisations like the UN and OECD in order to deal

\footnotetext{
${ }^{5}$ This author has recently engaged in more detail with transnational law in the public-private interface elsewhere (Buhmann 2015, Buhmann forthcoming).
} 
with societal problems caused by TNCs and other business, having emerged as powerful actors at the global stage.

Conventional international law relates to obligations (or corresponding rights) that states would agree to vis-à-vis each other. With the evolution of international human rights and humanitarian law, international law came to regulate states' obligations vis-à-vis individuals within their own territories, and to create corresponding (human) rights. Still, such obligations are held towards other states, even when they also mean a duty to protect against horizontal human rights violations between individuals, as when a company violates human rights (Ruggie 2013, Knox 2008, Jägers 2002).

With a few exceptions, mainly under international environmental law, corporations have so far not been made duty-bearers under international law. Technically nothing legally prevents the creation of obligations under international law for corporations. The evolution of such corporate obligations has been held back by a combination of traditionalist thinking among international lawyers (Alston 2005) and corporate lobbying along with political interests of some states (Kinley and Nolan 2007, Backer 2006). This combination of economic interests, politics, public policy and doctrinal international law creates a situation in which it has turned out to be difficult in practice for organisations like the UN level, to regulate TNCs.

The UN, the world's largest intergovernmental organisation, has extensive objectives as to social development (UN 1945, article 1) but only limited powers to implement these. That is particularly the case in relation to sustainability related global concerns, including human rights. These are increasingly at risk of violation by the private sector, especially when governments neglect to implement international obligations, leading to governance gaps. Indeed, within the human rights context, business capacity to cause harm is recognised to often be a result of governance gaps (Ruggie 2004, 2007). Due to weak enforcement institutions, conventional international human rights law is ill equipped to dealing effectively with governance gaps that allow business caused human rights violations within or across the boundaries of nation states.

Unlike the UN and the OECD, the EU may adopt hard law with direct effect for companies. However, the EU has limited law-making powers with regard to some typical CSR issues, especially labour and human rights. Law-making in these areas typically either remains with Member States' governments or is shared with these.

National law is limited by jurisdictional boundaries that are typically territorial (Zahle 2005). Due to political and economic considerations of both home and host states, extraterritorial regulation by business home states to limit adverse business impact on host states is an exception.

\subsection{Transnational regulatory theory}

Against this background, transnational legal theory offers a pragmatic approach that allows scholarly observation of the evolution of law across established boundaries between the legal systems of international or national law, and between public and private actors (Koh 1997, Zumbansen 2012). Transnational law is not 'stateless' (Teubner 1997, 2000): it explicitly recognises a interrelationship between public and private law across both national boundaries and boundaries of types of legal systems (not only national, but also between the international and national systems of public law) (Koh 1997, Eberlein et al 2014, Guldbrandsen 2014). In line with 
the theoretical approach, the transnationalisation of law allows for shifts of legal norms of conduct across these boundaries. Norms originally formulated as international norms for states (such as human rights) have already long been part of the social expectations on business and even private CSR Codes of Conduct.

Thus, transnational law allows a role for states and organisations created by states (such as the UN and OECD) in actively involving businesses to address concerns of a transnational character. Interaction between companies and public international law-makers has been recognised as potentially important for business acceptance of norms on corporate conduct (Friedmann 1964, Charney 1983, Picciotto 2003, 2011). Indeed, this was crucial for the broad acceptance of the UN Framework and UNGP (Ruggie 2013, Buhmann 2012). Testing effects is too early, but international law and transnationally oriented legal theory complemented by political science recognises that the involvement of those subject to rules favours a 'compliance pull', meaning that normative directives are respected even without strong enforcement institutions (Franck 1990, Shelton 2006, Guldbrandsen 2004, Lambooy 2009, Risse \& Kleine 2010.)

The UNGP have the character of an international soft law instrument. Although entitled a policy document, the UN Framework effectively is much like a soft law international instrument. OECD's Guidelines for Multinational Enterprises as well as CSR transparency or reporting requirements, based in national or EU law, have transnational impact through their intended influence on business organisations operating outside the borders of the home country. Through the theoretical lens of transnational law, it is therefore possible to observe the way in which the UN Framework and UNGP have influenced other public regulation in other legal systems, whether under another international organisation the OECD, the EU or nation states. This allows us to observe a juridification in which public regulators engage in regulating CSR through novel approaches that are transnational by functioning across conventional legal boundaries.

\section{Literature review}

Juridification is an expansion of law into fields beyond law. It entails a legal framing of societal phenomena (such as social expectations of companies), a proliferation of law into other fields of practice or science (such as politics or ethics), or an increased regulation by law of social actors or processes (Blichner and Molander 2005, Habermas 1981). Observing processes of juridification offers opportunity for analyzing effects and opportunities, and by implication the potential for shaping business impact on society through public regulatory measures. Importantly, 'juridification' relates not only to hard, enforceable law, but also to soft law and mixed forms like guidance and incentives, such as business transparency on CSR practices and mandatory reporting that counts on market based reactions as 'sanctions' as much as legal enforcement. Interaction between legal forms and systems, such as normative influence of international law on national law and business decisions have potential for juridification when they spread beyond their conventional confines.

The influence that the UN Framework and UNGP have had already, noted above, suggest a juridification of CSR. To understand why this is happening, SLO matters. Not only was the concept explicitly referred to in the UN Framework and UNGP, which were based on the UN's public policy objectives noted above to ensure protection of human rights. Analyses for the instruments also indicated significant costs to business resulting from loss of SLO, and discovered that registered as general operational costs these often remain unperceived (Ruggie 2013). 
The SLO concept emerged relatively recently in the academic literature, and is still subject to clarification. Inspired by mining sector practices, the term has mainly been discussed in the natural resources literature (Prno \& Slocombe 2012, Owen \& Kemp 2013; Burke et al. 2011, Nelken 2006). Prno \& Slocombe (2012) claim that there is broad recognition that mineral developers need to gain SLO from local communities in order to avoid potentially costly conflict and exposure to social risks, and that SLO can be considered to exist when a (mining) project is perceived to have ongoing approval and broad acceptance of society. Owen and Kemp (2012) argue a need for the mining industry to reconcile internal risk-orientation with stakeholder engagement and orientation. SLO expresses an ongoing acceptance among stakeholders affecting its legitimacy and, by implication, conditions for functioning (Holmström 2010, Nelken 2006).

Early academic papers on the Global Compact argued that "social, environmental or human rights issues" are of indirect but nevertheless significant concern to business due to the interrelationship between external and internal needs with direct impact on companies' bottom line (Kell \& Ruggie 1999). Arguments offered for developing the UN Framework resonate similar reasoning, emphasising the significance of global social concerns for companies to appreciate the implications and conditions of SLO (Buhmann 2014).

Byrne (2011) holds that business ethics studies tend do be limited to exploring components of ethically good business, and that this affects scholarly advancement of respect for human rights. Byrne holds that international attention to business related human rights abuse calls for a shift in focus. Sen (2004) argues that human rights as moral norms have authority beyond law. Arnold (2010) discusses the three 'Pillars' of the UN Framework as combining moral as well as legal and political aspects. Bernaz (2012), Muchlinsky (2012) and McCorquedale (2009) demonstrate that the UN Framework and UNGP influence business activities and legitimacy. Adopting process oriented approaches discussing the interplay between international human rights law and CSR, several authors have argued that international human rights law translates into both hard and soft responsibilities for companies (Knox 2012, Muchlinski 2007, Backer 2006, Mares 2006, Jägers 2002). Emerging transnational regulation based on the UNGP has been recognised as a measure to address governance gaps with important implications for business conduct in relation to human rights (Footer 2002, Jägers 2012).

Mirroring the voluntary-mandatory dichotomy, the background to the evolution of public regulation of business impact on society, whether soft or hard, has tended to be discussed in the legal rather than the organisational literature (e.g., Kinley and Nolan 2007, Mares 2012a). However, also aptly mirroring later years' softening of that dichotomy (Mayer 2009, Wettstein 2009, Mares 2012b, EU 2011) legal scholars increasingly address business ethics issues in interdisciplinary or socio-legal perspectives (e.g. Horrigan 2010, McBarnet 2008, Buhmann, Roseberry and Morsing 2011). Fundamental institutional limits between international law and national law, public law and private law, public law capacity to regulate transnational business activities and responses through emerging transnational or 'global' law have been addressed in the legal literature (e.g., Teubner 1997, 2000, Trubek 2004, Krisch 2010, Krisch and Benedict 2006).

A plethora of private or public-private guidelines, reporting schemes and codes of conduct have emerged in later decades to guide companies towards managing and limiting their adverse impact on society. Many emerge in response to social expectations, based on recognition that reputation and stakeholders' perception of a business organisation affect its SLO (Burke et al. 2011, Holmström 2010, Nelsen 2006, Gunningham et al. 2004). With national and particularly 
international regulators developing guidance and regulatory schemes to shape businesses conduct and their impact on society, an emerging literature discusses CSR in the context of public policy, or even as a subject of public regulation.

There is increasing scholarly questioning of the 'public-private' or 'voluntary-mandatory' dichotomies (Devinney, Schwalbach \& Williams 2013, Raelin \& Bondy 2013, Brammer, Jackson $\&$ Matten 2012) and observation that the division of tasks between governments and business is giving way to a more integrated approach to address public policy objectives (Scherer and Palazzo 2011, Gjølberg 2010, Auld, Bernstein \& Cashore 2008). Increasingly explicit governmental regulation feeds this debate empirically and conceptually (Knudsen \& Brown 2014, Knudsen \& Moon 2012, Fairbrass 2011, Buhmann 2011a, 2011b, Steurer 2010, Steurer \& Margula 2009). The regulatory capacities of CSR are noted to work as a novel (or 'new') governance mechanism complementing and interacting with other regulatory forms (Rasche 2010, Hess 2008, Blair, Williams \& Lin 2008, Meidinger 2006). Interaction between public and private regulatory governance and a transnationalisation of law are discussed as solutions to limitations of conventional law's regulation of transnational economic activity in accordance with public policy goals (Eberlein et al 2014, Abbott and Snidal 2013, Zumbansen 2012). The business perspective has given way to debate on the mutual influence between governmental and business interests in CSR to create 'shared value' (Porter and Kramer 2011). An emphasis on CSR being based mainly on business interests in terms of 'doing well by doing good' (Porter \& Kramer 2006, Smith 2005, Berman et al. 1999) is complemented by recognition of CSR as a measure to address public policy interests or indeed the firm as a political actor (Walsh 2005, Frankel 2004). Matten and Moon's (2008) implicit-explicit CSR recognises that company conduct, especially in Europe, is influenced by governmental objectives. Jackson and Apostolakou (2010) argue that CSR may be emerging as a substitute for formal institutions and social regulation.

Organisational literature has taken to analysing how governments and intergovernmental organisations address CSR and what causes authorities to adopt measures to promote business selfregulation with the aim of minimising adverse impact on society (Rasche 2010, Margula \& Steurer 2009, Reich 2007, Moon 2004, Haufler 2001, Gjølberg 2010, Strand 2009). Discussing political CSR, Scherer and Palazzo (2011) demonstrate that the division of tasks between governments and business is giving way to a more integrated approach in which companies not only assume social responsibilities that go beyond legal requirements, but also assume tasks which are basically of a political nature. These are tasks which are basically legal obligations or policy objectives of governments or authorities at international, supranational, national or local levels, such as the implementation of human rights or the provision of labour and inclusive employment practices (Buhmann 2011a).

Yet business ethics and organisational literature tends to focus on how politicization of business is observable or justifiable from the business perspective. The reason why public regulators have taken to seek to steer business ethics normativity and how they do so at various levels of governance that affect business organisations in a globalised world remain much less discussed and understood in the literature. Authorities' regulation of CSR, whether at intergovernmental or governmental level, tends to be explained as 'necessary supplements' (Rasche 2010), 'implicit' CSR (Matten \& Moon 2008) or exceptions from the rule of voluntarism (Wettstein 2009). Auld, Bernstein and Cashore (2008) distinguish between several CSR categories including public-private partnerships and the drive towards fulfilling public policy objectives, such as human rights. However, their categorisation fails to note actual intergovernmentally driven development of CSR 
norms (such as the UNGP) or CSR activities based on governmental directives (such as mandatory CSR reporting). Such norms and directives are not simply yet another category of CSR. Rather, intergovernmentally driven development of CSR norms and CSR activities frame an entire norm-set of what constitutes socially responsible business conduct. Indeed, they are born out of regulatory aims to promote the implementation of public policy objectives beyond the limits of conventional regulatory boundaries (Buhmann 2011a, 2013).

Scherer and Palazzo (2011) note emerging debates in legal studies related to political CSR, such as the impact of globalisation on the regulatory power of state institutions, the blurring of boundaries between the public and the private, and the difficulty of international organisations like the UN in filling governance gaps resulting from states' lack of will or capacity. They argue that a new form of transnational regulation is arising with private actors and multi-stakeholder initiatives filling governance gaps. The authors convincingly assert that the CSR literature has not yet sufficiently integrated the new political role of private business. They argue that much of the literature pursues an instrumental view of CSR and builds on an economic paradigm which advocates a strict separation of political and economic domains. The 'political CSR' perspective "suggests an extended model of governance with business firms contributing to global regulation and providing public goods" (2011:900-901). Yet they do not engage with what this means for public regulation to shape CSR.

\section{SLO and the UN instruments}

The UN Framework adopted the extractives literature concept and broadened it to the make explicit the connection between business related societal risks and economic risks to business. The argument was that when business is seen to harm societal interests in pursuit of its own interests, adverse impact of business activity on human rights reduces the organisation's SLO (SRSG 2007, UN 2008:para. 54). The UN Framework specifically states that social expectations are as important for a company's SLO as is legal liability (UN 2008:paras. 54-55)

With the UN Framework leading to the UNGP, the SLO argument implicitly informs the latter. Indeed, articulation of economic interests and risk of profit loss were significant for business support for the UN Framework and UNGP (Buhmann 2012). SLO arguments functioned to connect business and social interests in better understanding of adverse business impact on society and 'smart' regulatory prevention. Both instruments emphasise that failure to understand and prevent adverse human rights impact represent significant economic risks to business organisation. Analyses undertaken during the development of the instruments showed a direct correlation between loss of SLO due to adverse human rights impact and economic losses through reduced recruitment opportunities, strikes, community blockades of transport, lost contract opportunities and other events affecting production and sales (Ruggie 2013:148-149). The considerable costs that social conflicts may cause to business operations have been further substantiated by a recent UNGP based study (Davis \& Franks 2014).

Both instruments offer detailed guidance for business organisations' engagement human rights related risk management, with the SLO serving as a significant part of the reasoning. The acceptance that this generated differed significantly from both business and government reception of the previous UN effort to guide responsible business conduct, the UN Norms.

The application of SLO in the UN Framework institutionalises the concept as derived from the extractives field but adds focus on the inherent economic risks to business by causing societal risks 
that run counter to social expectations, public policy objectives or governments' legal obligations. It also connects economic and social interests to generate support for the Framework, which as section 7 elaborates influenced broader public regulation of CSR.

The UN Framework and UNGP draw a direct line between on the one hand, social expectations and political and legal demands on business in national and transnational contexts of operation, and on the other public policy objectives and regulatory options and obligations of international and national public regulators. They set out specific reasoning and recommendations for transformation into action, which in several cases involved SLO and have translated into public CSR regulation beyond human rights.

Social risks challenge the UN's effectiveness in implementing its objectives. Through social, environmental and economic costs to society they challenge governments' effectiveness to implement public policy to protect against such risks. For the UN Framework and UNGP, explicit or implicit references to SLO demonstrate the sometimes thin line between social expectations, policy objectives and law: legal liability may arise due to disrespect for human rights, yet for SLO the impact of reactions by stakeholders in the 'courts of public opinion' (UN 2008, para. 54) may be at least as detrimental. Relating this to an elaboration of the state duty to protect and recommending implementation through a regulatory mix including guidance, incentives, and transparency requirements, the UN instruments spurred the broader process of public regulation of CSR.

\section{Public regulation of CSR}

\subsection{The UN Framework and Guiding Principles}

Because the corporate responsibility to respect includes both compliance with applicable law and respect for human rights in terms of social expectations and SLO, there is a close connection with both national and international human rights law. The UN Framework and UNGP establish this through the state duty to protect, which entails that states must ensure protection for individuals against human rights abuses by a third party (including businesses) through appropriate policies, regulation, and adjudication (UN 2011 para. 6, Chapter I). This is already a duty of states under international human rights law, but the UNGP elaborate specific action to be taken by states. For example, UNGP principle 3 and its commentary explain that states should not only enforce laws requiring companies to respect human rights. They should also ensure that corporate law and policies for setting up and operating businesses enable rather than constrain business respect for human rights. The UNGP recommend a "smart mix" comprising both mandatory and voluntary measures to enhance business respect for human rights. For example, states may provide guidance for companies on how to respect human rights and may complement this by encouraging or even requiring companies to communicate how they address their human rights impact. As will be seen, this approach and some of the terminology were adopted by both the EU for the 2011

Communication and the Danish government for its CSR communication requirements.

In line with this, the UNGP explain that authorities should explicitly communicate that they expect all business enterprises domiciled in their territory and/or jurisdiction to respect human rights throughout their operations (Principle 2). This takes issue with the territoriality constraint by asking states to make their expectations of companies clear, whether the company operates inside that state or is based in the state and operates outside it. It assumes a connection between law, social expectations and policy that builds on SLO reasoning in the UN Framework. 
The UNGP explain that states need to ensure human rights respect by state-owned or statecontrolled enterprises and in their own commercial activities, for example through requirements in investment treaties or contracts (Principles 4-6). The latter is potentially quite significant because states and government organs have considerable impact on companies through their public procurement policies, laws and contracts.

These points establish several links to business requirements that are or could be based in law, ranging from mandatory requirements to 'smart mix' elements working through incentives. These are further strengthened by detailed recommendations on human rights due diligence, comprising both a voluntary business element and a 'smart mix' or mandatory state element. Detailed provisions recommend that companies undertake human rights due diligence to avoid or mitigate human rights abuse (Principles 17-21). States may encourage or require companies to conduct human rights due diligence. Entailing detailed assessment of the current and future human rights impact of current and planned activities and mitigation of identified risks, human rights due diligence may complement legal liability by reducing the case for liability to arise. Thus, the UNGP underscore the potential of public policy and law - including but not limited coercive law - to influence company action and reduce adverse human rights impact.

With several of the Principles relating to management processes, the UNGP connect to the UN Framework's observation on the significance of social expectations for a company's social licence to operate (UN 2008 paras. 54-55). The implications are direct for business management: business enterprises should have policies and adopt processes to meet their responsibility to respect.

The third part of the UN Framework, on access to remedy, applies to both states and companies. Companies should establish processes to deal with complaints, and states should facilitate access to such mechanisms (Principles 25-28). This includes the NCP complaint modality under OECD's Guidelines. The process should also be based on engagement and dialogue (including with stakeholders) to solve the conflict (Principle 31). In this way remedial processes may strengthen a business management's understanding of the reasons for conflict and generate learning feeding into procedures to avoid human rights abuse.

\subsection{The 2011 revision of OECD's Guidelines for Multinational Enterprises}

Because the OECD as an international organisation is distinct from the UN, there is no confluence between UN and OECD soft or hard law by default. Therefore, the fact that the 2011 revision of OECD's Guidelines is strongly influenced by the UN Framework and UNGP testifies to explicit efforts by international public regulators to streamline and expand norms on responsible business conduct. Showing substantive as well as textual influence from the UN instruments, the Human Rights chapter, added through the 2011 revision, states that enterprises shall prevent or mitigate human rights impact directly linked to their business operations, products or services, and avoid contributing to human rights abuse caused by others. Similarly, it notes that they should have a policy commitment on human rights, carry out human rights due diligence, provide for remedy and/or cooperate with remedy institutions, such as NCPs.

Significantly, the 2011 revision of OECD's Guidelines not only adopted the process oriented the due diligence approach to human rights introduced with the UN Framework and UNGP, but expanded it to most of the issue areas addressed by the Guidelines. Accordingly, enterprises are now expected to exercise due diligence with regard to all substantive issues of the Guidelines except for science and technology, competition and taxation (OECD 2011, Commentary to General 
Principles, para. 14). The importance of this broadening of the due diligence approach applied by the UN's guidance on business and human rights is potentially immense, because OECD practice allows for exchanges between NCPs regarding cases. Thus, learning on what is required by due diligence may expand and be transferred between issue areas and across national boundaries of NCPs and companies operating in or from adhering countries. This may contribute to social expectations on responsible business conduct and in turn to enhancement or threat to businesses' SLO, depending on how a business responds to these expectations.

Other important features of the revised Guidelines testifying to influence from the UN instruments is the recognition of the full spectrum of the International Bill of Human Rights, compliance with national law as comprising the normative framework within which enterprises should operate, and host states' own international human rights obligations as part of this. Other significant changes bearing witness to elements in the UN instruments include a reference to meaningful stakeholder consultation, and broadening the scope of the Guidelines to apply not just to production but also to the financial sector.

\subsection{CSR transparency and mandatory reporting: $E U$ and national regulatory measures}

A policy document, an EU Communication can set directions for new EU law. The influence of the UNGP on the EU's 2011 CSR Communication is evident in several ways, including that human rights should be given greater attention as a prominent aspect of CSR (section 2), and a full subsection (4.8.2) on the Commission's proposals for implementation of the UNGP within the EU Member States. This includes both guidance for businesses ${ }^{6}$ which may assist them in exercising human rights due diligence, and steps to promote transparency on CSR through reporting.

Alluding to the SLO, the Communication notes that to "fully meet their corporate social responsibility" enterprises should integrate social, environmental, ethical, human rights and consumer concerns into their business operations with the aim to identify, prevent and mitigate possible adverse impact. This wording reflects the UNGP's due diligence approach and, importantly, broadens it to CSR issues beyond human rights. Making direct reference to human rights, the reporting policy bears witness to the influence of the UNGP as well as to their recommendation that authorities introduce non-financial reporting as a measure to influence business conduct.

A clear example of the EU's shift from the 'voluntary' approach to explicit public regulation of CSR and deploying a term introduced in the UNGP, the Communication notes that public authorities should promote CSR through a "smart mix" of regulatory measures. Connecting to hard and soft law as well as incentives, the smart-mix approach was intended to promote, create market incentives and ensure accountability (EU 2011 section 3.4). Indeed, new transparency requirements for EU based businesses build on the 2011 Communication. Large companies will be required to disclose information on policies, risks and results on respect for human rights, environmental matters, social and employee-related aspects, anti-corruption and bribery issues.

Mandatory CSR reporting and specific reporting on human rights introduced by the Danish government demonstrate the influence of the UN Framework and UNGP at the level of national law. Denmark is an EU Member State but introduced mandatory CSR reporting before the $2011 \mathrm{EU}$ Communication. For the purposes of such reporting, the Danish reporting clause defines CSR as the

\footnotetext{
${ }^{6}$ In 2012 and 2013 the Commission published human rights guidance for SMEs as well as businesses in the extractives, IT and recruitment sectors.
} 
integration of human rights, social issues, environment, climate and anti-corruption in companies' policies and practices. CSR reporting has been mandatory since 2009 for large Danish private and state-owned companies and institutional investors (Buhmann 2013). The reporting requirement was based on a policy document ('Action Plan') on CSR from the Government, which referred to the UN Framework (Danish Government 2008). Making reference to the UNGP, the government introduced a strengthened reporting requirement, mandating reporting on human rights policies in 2012 (Act 546/2012, section 11, Danish Government 2012).

The Danish case exemplifies an effort to promote CSR through a smart mix approach. The reporting requirement is technically hard law, but it invokes sanctions that are market based. Transparency in terms of CSR reports enables civil society monitoring and social and economic sanctions. Enforcement through legal sanctions (administrative fines) is light so far, and the official approach also counts on dialogue and encouragement by the government in order to induce learning (Buhmann 2013). Inducing transparency is deployed by the government as a measure to enable civil society to hold companies to account in terms of their reputation and SLO. In line with reasoning in the UNGP, reporting and transparency are intended to encourage companies to internalise human rights and other CSR related concerns within as well as beyond the boundaries of the government's territory and jurisdiction. Thus, the reporting requirement complements the conventional public national and international law regime in relation to adverse business social and environmental impact.

\section{Discussion}

Initiated at a background of political stale-mate and concern with the adverse and often transnational impact of business on human rights that conflict with the human rights policy objectives of the UN, the UN Framework and UNGP were developed as innovative ways for the UN to address business related human rights abuse. The Framework and UNGP address business and human rights from the perspective of business as well as states, and with regard to impact in and responsibilities of both home and host states. Through their detailed elaboration of the implications of the UN Framework for business as well as states, and their actual influence on initiatives by other regulatory organisations or states, the soft law UNGP are transnational in scope. The UN Framework and UNGP address governance gaps by reaching beyond the limitations of conventional public international and national law. Offering normative guidance for businesses in the form of soft law from the UN, a state-based organisation, the UNGP constitute a form of public regulation relating to responsible business activity. Adopting elements offered by the UN guidance on business and human rights, other public regulatory organisations - the OECD, EU and nation states - have further advanced transnational regulation of business conduct, deploying their powers to establish hard law, regulatory mixes and enforcement.

The significance of a business organisation's SLO was noted by the UN Framework as a major reason why business organisations should respect human rights. The economic risk that human rights violations may cause to the interests of business through reduced SLO therefore forms a key element in the value of the UNGP for both business and society. By implication, it is also a key element in other forms of public law that build on the UN's guidance on business and human rights.

The UNGP's elaboration of the state duty to protect combines mandatory and voluntary approaches in several ways with impact on business activities and management decisions on business ethics. States may employ a 'smart mix' of regulatory modalities to promote business respect for human 
rights through both legal requirements and voluntary action; and states may require or encourage companies to report on what they do to live up to their own human rights responsibilities.

For the UN Framework and UNGP, SLO runs as an important undercurrent for both businesses and governments to implement measures to ensure business respect for human rights. By implication, the emergence of detailed guidance on how to address such adverse impact and the integration of this guidance into other transnational business governance instruments are important steps for both businesses and societies towards upholding SLO for businesses. At the same time, the adoption of such guidance and its integration into public regulation at international and national level entails a novel development in the regulation of business conduct as to CSR issues, which had previously been dominated by private regulation.

The analysis above has demonstrated that social expectations of business and their influence on the SLO permeate the way regulators seek to influence business conduct. Through the UNGP, the UN Framework's recognition of the significance of the SLO was operationalised into direct recommendations to companies to undertake human rights due diligence and ensure transparency, and for public regulators to promote such transparency. Through influence on the OECD Guidelines the recommendations transform into state actions to strengthen National Contact Points (NCP) to offer increased access to remedy. Through NCP practice and exchanges, due diligence requirements may become elaborated and inform both social expectations and governmental recommendations or even requirements on business.

Through influence on EU initiatives on CSR and national law, the UN guidance is becoming transferred into direct policy, legislative proposals and requirements, and 'smart mix' regulation. These initiatives seek to induce business self-regulation on human rights through the modalities of CSR transparency and reporting. Facing businesses with potential civil society critique and reputational accountability, these measures draw on business interest in preserving its SLO. The SLO is often based on social expectations of business to act in accordance with certain moral foundations, which for practical purposes often correspond to obligations that states are bound to protect as human rights. Precisely because businesses are not subject to such formal obligations under international human rights law, the social expectation that they observe similar standards of conduct connects to their SLO.

Through the formalisation of normativity on business and human rights the politicization of business has entered a new stage marked by an increasing juridification. The UN Framework and UNGP have spurred a chain of public regulatory initiatives with diverse organisations. Deploying soft or mixed forms of regulation, much of this is caused by efforts to reach beyond the limits of conventional public law. CSR transparency recommendations and reporting requirements indicate that voluntary CSR measures and those resulting more directly from the UNGP reinforce each other. The agreement that marked the adoption of the UN Framework and the UNGP not only among governments but also business and civil society organisations enabled a shift from the broad politicization of business which often left businesses without clear indications as to what is expected of them, to a series of more explicit expectations based in soft and hard law. The due diligence process, proposed by the UN instruments and adopted by the OECD for a broad range of CSR issues, is a case in point.

Based on a transnationalisation of law which reaches beyond conventional boundaries limiting public law, these developments entail a legal framing of social expectations of companies. Entailing 
juridification, this results in a proliferation of law into the field of business ethics, and an increased regulation by law of social actors or processes that were hitherto the subject of business decisionmaking and strategy and approached as a politicization of business.

For businesses' SLO, the implications are not only significant with regard to human rights. The detailed guidance on business and human rights offered by the UN Framework and the UNGP may be expected to influence public policy and legal measures on CSR in a broader sense. The range of issues covered by OECD's Guidelines as well as due diligence recommendations based on the UNGP are cases in point. So are recommendations and requirements on CSR transparency at EU and national levels.

Emerging and solidifying unified understanding in public regulation across diverse international organisations (the UN, OECD and EU) and national regulators on what is expected or even required of a company in terms of due diligence related to its impact on society provides increased certainty to the company of what is expected, making it simpler to uphold the SLO. It also informs social expectations and therefore conditions for SLO, contingent on the company' observance or nonobservance of what is expected. Underscoring the transnational interaction, transparency voluntary or required by EU or national law - enables civil society monitoring of observance.

\section{Conclusion}

This article has explored how the soft law UNGP and the UN Framework have influenced and spurred other public regulatory initiatives to promote CSR. Doing so offers a public regulation perspective that complements the 'political CSR' debate. The article has shown how public regulators increasingly engage with promoting private organisations' CSR efforts, that these are based on constraints in conventional public law to implement public policy objectives affected by businesses, and that these efforts to promote 'political CSR' are evolving into a juridification functioning through diverse regulatory modalities with different regulatory organisations, ranging from soft law guidance to regulatory mixtures of transparency and due diligence recommendations and hard law requirements, and remedial institutions with extraterritorial reach. We have shown that characteristics of public international and national law hold a key to understanding much of the new public role in CSR. Institutional characteristics and limitations combine with public policy objectives, which increasingly extend beyond the regulatory boundaries of nation states. The transnational regulatory influence which the UN Framework and UNGP have had already in the field of business and human rights and even beyond (for example through the influence on the OECD Guidelines and CSR transparency measures), indicates the potential significance of the emerging juridification of CSR. Public influence goes from being soft and indirect through guidance and social expectations influencing the SLO, to becoming hard and direct through transparency and due diligence requirements.

The UN Framework applied the SLO concept to explain the 'Corporate Responsibility to Respect' as having economic, societal and legal aspects related to public policy and interests. This responsibility may occasionally be met by sanctions by courts, but as importantly is based on social expectations. This application of SLO potentially both institutionalizes it beyond the original extractives sphere and adds to it by explicating connections between ethical, economic and legal aspects of CSR. 
Based on agreement within the UN and external stakeholders concerned with CSR, which was assisted through articulation of SLO related interests, the UN Framework and later the UNGP facilitated public regulation of CSR. They did so by recommending how governments may address CSR-related problems affecting public policy interests both within and outside their borders by hard, soft and mixed forms of law.

The 2011 revision of OECD's Guidelines for Multinational Enterprises, the EU's 2011 revision of its definition of CSR, and mandatory CSR reporting for EU-based and some national companies bear witness to this influence that is leading to a juridificationof CSR beyond the human rights focus of the UN Framework and UNGP.

Regulating CSR enables national governments and international organisations to reach beyond their territorial limits. Explaining this as a reason for why public regulators seek to shape CSR, and showing how such regulation may entail soft, hard and mixed forms, this article has added to scholarly insight and theory on the interplay and mutual impact of public regulatory instruments that seek to shape business conduct as regards CSR. Based on the impact of the UNGP we have demonstrated how the politicization of business is evolving into juridification through the development of soft guidance and its transformation into law.

Looking at the UN Framework and UNGP and their influence through transnational regulatory theory as a lens for observation, this article has shown that the politicization of business is turning into a juridification with the SLO working as an important lever both from the perspective of business and societies. The discursive articulation of the potentially adverse economic risks caused by business impact on human rights through reduced SLO contributed to generating business support for the Framework and UNGP. With this support the UN was able to overcome conventional limitations and produce a novel form of regulation, which is transnational in scope. The background was an aim to address problems deriving from governance gaps and adverse societal impact of economic activity that escape much conventional international or national regulation. As part of the method to reach this aim, mixed forms of regulation that avoid the territorial limitations of conventional public law were introduced or encouraged. Connected through SLO, social expectations, the soft law UN guidance and existing as well as emerging hard law shows how ethics, politics and law may interact and lead to a juridification of issue such as CSR, which until recently was mainly seen to be distinct from regulation through public law.

Influencing public regulation at the level of the OECD, the EU and nation states, the UN's guidance on business and human rights have resulted in a series of regulatory initiatives on business responsibilities for human rights that interact to mutually support and reinforce each other. As a result, authorities' expectations on businesses with regard to human rights due diligence and the provision of complaints options are solidifying with a shared point of departure in the UN Framework and UNGP. CSR transparency requirements enable civil society to learn what businesses do in response to such expectations, and to respond through the force of the market if they are unhappy with what they see. Thus, social expectations and the SLO are connected through the mixed regulatory forms introduced based on the UN's guidance on business and human rights.

The fact that not only the UN but also the OECD, the EU and national regulators move towards defining minimum norms of conduct for business conduct and providing guidance for implementation testifies to the growing agreement across organisations, regions and states as well as non-state actors of the pertinence in regulating business impact on society by indicating to companies what society expects of them besides compliance with applicable national law. This 
development is nourished by a convergence among public regulators at diverse levels in how to address adverse impact on society resulting from business activity. While specific activities remain at the discretion of companies, governmental and intergovernmental authorities actively seek to shape business action through transnational regulatory modalities that play on the willingness and interest of businesses to adapt to social expectations in order to preserve their SLO. Recent years' UN guidance on business and human rights with their emphasis on the SLO has played a significant part in this process.

Exploring the juridification of CSR from the perspective of public regulation, the article adds novel perspectives to private or public-private regulatory initiatives in the field, such as the Kimberley process on responsible diamonds and the Extratives Indutries Transparency Initiative (EITI) that have a more limited sectoral focus. As clearly demonstrated by the OECD Guidelines' broad application of the due diligence approach propounded by the UN Framework and the UNGP, the effects of this UN guidance on a juridification of CSR is neither limited to human rights, nor to specific sectors.

It is too early to assess whether the juridification of CSR spurred by the UN Framework and UNGP in fact affects CSR uptake among firms. This offers a research perspective to be addressed by future research. Such research may also assess how SLO functions as a driver for businesses' appreciation of the objectives intended by public regulators when the latter seek to institutionalise CSR through soft, hard or mixed forms of public law.

\section{References}

Abbott, K.W. and Snidal, D. (2013). Taking responsive regulation transnational: Strategies for international organizations. Regulation \& Governance 7(1), 97-113

Act 546/2012 on a Complaints and Mediation Institution for Responsible Business Conduct, 18 June 2012.

Alston, P. (2005). The 'Not-a-Cat' Syndrome. In P.Alston (ed.) Non-State Actors and Human Rights (3-36). Oxford University Press, New York

Arnold, D. (2010). Transnational Corporations and the Duty to Respect Basic Human Rights. Business Ethics Quarterly 20(2), 371-399.

Auld, G., Bernstein, S. and Cashore, B. (2008). The new Corporate Social Responsibility. Annual Review of Environmental Resources 33(1), 413-435

Backer, L.C. (2006). Multinational Corporations, transnational law: The United Nations' Norms on the Responsibilities of Transnational Corporations as a harbinger of Corporate Social Responsibilty in international law. Columbia Human Rights Law Review 37, 287-389

Berman, S.L., Wicks, A.C., Kotha, S. and Jones, T.M. (1999). Does stakeholder orientation matter? The relationship between stakeholder management models and firm financial performance. Academy of Management Journal 42(5), 488-506 
Bernaz, N. (2012). Enhancing Corporate Accountability for Human Rights Violations: Is Extraterritoriality the Magic Potion? Journal of Business Ethics 117(3), 493-511

Margaret M. Blair, Cynthia A. Williams and Li-Wen Lin (2008) The Roles of Standardization, Certification and Assurance Services in Global Commerce, Osgoode Hall Law School Research Report No. 12/2008, available at http://digitalcommons.osgoode.yorku.ca/cgi/viewcontent.cgi? article=1186\&context=clpe last accessed 23 October 2015

Blichner, Lars Chr. and Anders Molander (2005). What is juridification?. Arena Working Paper No.14, University of Oslo, Oslo

Brammer, Stephen, Jackson, G. and Matten, D.. (2012) Corporate social responsibility and institutional theory : new perspectives on private governance. Socio-Economic Review, Vol.10 (No.1). pp. 3-28

Buhmann, K. (2011a). Integrating human rights in emerging regulation of Corporate Social Responsibility: The EU case. International Journal of Law in Context, 7(2), 139-179

Buhmann, K. (2011b). The Danish CSR reporting requirement: Migration of CSR-related international norms into companies' self-regulation through company law? European Company Law, 8(2), 65-73

Buhmann, K. (2012). Business and Human Rights: Analysing Discursive Articulation of Stakeholder Interests to Explain the Consensus-based Construction of the 'Protect, Respect, Remedy UN Framework'. International Law Research, 1(1), 88-101

Buhmann, K. (2013). The Danish CSR reporting requirement as reflexive law: Employing CSR as a modality to promote public policy. European Business Law Review, 24(2), 187-216

Buhmann, K. (2014), Normative discourses and public-private regulatory strategies for construction of CSR normativity.Multivers Academic, Copenhagen

Buhmann, K. (2015) Business and Human Rights: Understanding the UN Guiding Principles from the perspective of Transnational Business Governance Interactions. Transnational Legal Theory Vol. 6 No 1 (2015), DOI 10.1080/20414005.2015.1073516

Buhmann, K. (forthcoming) Juridifying Corporate Social Responsibility through Public Law: Assessing coherence and inconsistencies against UN guidance on Business \& Human Rights. International and Comparative Corporate Law Journal, 11(3)

Buhmann, K, Morsing, M. \& Roseberry, L. (2011). Corporate Social and Human Rights Responsibilities: Global Legal and Management Perspectives. PalgraveMacmillan, London

Burke, R.J., Martin, G. and Cooper, C.L. (2011). Corporate Reputation: Managing opportunities and threats. Ashgate, London 
Byrne 2011: Edmund F Byrne (2011) Business Ethics should study Illicit Business: To advance respect for Human Rights, Journal of Business Ethics, November 2011, Volume 103, Issue 4, pp 497-509

Cassese, Antonio (2005), International Law. $2^{\text {nd }}$ edition. Oxford University Press, Oxford.

Charney, Jonathan L. (1983) Transnational Corporations and developing public international law, Duke Law Journal, Vol. 32: 748-788

Cragg, W. (2012). Ethics, enlightened self-interest, and the Corporate Responsibility to Respect Human Rights: A critical look at the justificatory foundations of the UN Framework. Business Ethics Quarterly 22(1), 9-36

Danish Government (2012). Responsible Growth: Action Plan for Corporate Social Responsibility. Regeringen, Copenhagen

Danish Government (2008) Action Plan for Corporate Social Responsibility. Regeringen, Copenhagen

Davis, Rachel \& Daniel Franks (2014) Costs of Company-Community conflict in the Extractive Sector. Corporate Social Responsibility Initiative, Report No. 66, Cambridge, MA: Harvard Kennedy School

De Schutter, O. (2013). Preface. In S.Deva, Surya and D.Bilchitz (eds) Human Rights Obligations of Business: Beyond the Corporate Responsibility to Respect?, (78-104).Cambridge University Press, Cambridge

Deva, Surya (2013). Treating Human Rights Lightly: A Critique of the Consensus Rhetoric and the Language Employed by the Guiding Principles. In S.Deva and D. Bilchitz (eds) Human Rights Obligations of Business: Beyond the Corporate Responsibility to Respect?, (78-104).Cambridge University Press, Cambridge

Devinney, T. M., Schwalbach, J. and Williams, C. A. (2013), Corporate Social Responsibility and Corporate Governance: Comparative Perspectives. Corporate Governance: An International Review, 21: 413-419. doi: 10.1111/corg.12041

Eberlein, Burkard, Kenneth W Abbott, Julia Black, Errol Meidinger \& Stepan Wood (2014) Transnational Business Governance Interactions: Conceptualization and framework for analysis, 8(1) Regulation \& Governance 1-21

EU (2013). Press Release: Commission moves to enhance business transparency on social and environmental matters. European Commission, Brussels, 16 April 2013

EU (2011). A renewed EU Strategy 2011-2014 for Corporate Social Responsibility. European Commission, Brussels. EU Doc. COM(2011)681 
EU (2002). Communication from the Commission concerning Corporate Social Responsibility: A business contribution to Sustainable Development. European Commission, Brussels. EU Doc. $\operatorname{COM}(2002) 347$

EU (2001). Promoting a European Framework for Corporate Social Responsibility'. European Commission, Brussels. EU Doc. COM(2001)366

Evald, J. (2005). At toenke juridisk [Legal thinking]. Copenhagen: Nyt Juridisk Forlag

Fasterling, B. and Demuinck G. (2013). Human Rights in the Void? Due Diligence in the UN Guiding Principles on Business and Human Rights. Journal of Business Ethics, DOI 10.1007/s10551-013-1822-Z

Footer, M. (2012). Shining Brightly? Human Rights and the Responsible Sourcing of Diamond and Gold Jewellery from High Risk and Conflict-Affected Areas. Human Rights and International Legal Discourse 6(1), 159-191

Franck, Thomas M. (1990) The power of legitimacy among nations, Oxford: Oxford University Press

Frankel, C. (2004). Virksomhedens politisering. Samfundslitteratur, Copenhagen.

Friedmann, Wolfgang (1964) The changing structure of international law, London: Stevens \& Sons Gjølberg, M. (2010). Varieties of corporate social responsibility (CSR): CSR meets the "Nordic Model”. Regulation \& Governance 4(2), 203-229

Guldbrandsen, Lars (2004) Overlapping public and private governance: Can forest certification fill the gaps in the global forest regime? Global Environmental Politics Vol. 4, No. 2: 75-99.

Guldbrandsen, Lars (2014) 'Dynamic governance interactions: Evolutionary effects of state responses to non-state certification programs', (8)1 Regulation \& Governance 74-92.

Gunningham, N., Kagan, R.A. and Thornton, D. (2004). Social License and Environmental Protection: Why Businesses Go Beyond Compliance, Law and Social Inquiry 29(2), 307-341

Habermas, J. (1981). Theorie des kommunikatives Handelns, Suhrkamp, Frankfurt am Main.

Haufler, V. (2001). A public role for the private sector: Industry self-regulation in a global economy. Carnegie Endowment for International Peace, Washington D.C.

Hess, D. (2008). The three pillars of Corporate Social Reporting as New Governance regulation: Disclosure, dialogue and development. Business Ethics Quarterly 18(4), 447-482

Holmström, S. (2010). Reflective management: Seeing the organization as if from outside. In R. Heath (ed) Handbook of Public Relation, (261-276).Sage, New York. 
Horrigan, B. (2010). Corporate Social Responsibility in the twenty-first century: Debates, models and practices across government, law and business. Edward Elgar, Cheltenham

Ioannou, Ioannis \& George Serafeim (2012), The Consequences of Mandatory Corporate Sustainability Reporting, Harvard Business School Working Paper 11-100

Jägers, N. (2012). Regulating the Private Security Industry: Connecting the Public and the Private through Transnational Private Regulation, Human Rights and International Legal Discourse 6(1), $56-91$

Jägers, N. (2002). Corporate Human Rights Obligations: In Search of Accountability. Intersentia, Antwerp.

Jackson, G. and Apostolakou, A. (2009). Corporate Social Responsibility in Western Europe: An institutional mirror or substitute? Journal of Business Ethics 94(3), 371-394

Kell, Georg and John G. Ruggie (1999) Global Markets and Social Legitimacy: The Case of the 'Global Compact', paper presented at York University, Toronto, Canada , 4-6 November 1999

Kinley, D. and Nolan, J. (2007). Trading and Aiding Human Rights in the Global Economy, Nordic Journal of Human Rights 7(4), 353-377

Krisch, N. (2010). Beyond Constitutionalism: The pluralist structure of postnational law. Oxford University Press, Oxford.

Krisch, N. and Kingsbury, B. (2006). Introduction: Global governance and global administrative law in the international legal order. European Journal of International Law 17(1), 1-13

Kennedy, D. (1987). The sources of international law. American University Journal of Law \& Policy 2(1), 1-96.

Knox, J.H. (2012). The Ruggie Rules: Applying human rights law to corporations. In R. Mares (ed) The UN Guiding Principles on Business and Human Rights, (51-83). Brill, Antwerp.

Knox, John H. (2008) Horizontal human rights law, American Journal of International Law, Vol. 102: $1-47$

Knudsen, Jette Steen \& Dana Brown (2014) 'Why Governments Intervene: Exploring Mixed Motives for Public Policies on CSR' Public Policy and Administration (April issue).

Koh, H. (1997). Why do nations obey international law? (Review essay). The Yale Law Journal 106(8), 2599-2659.

Lambooy, Tineke (2009) Private regulation: Indispensable for responsible corporate conduct in a globalizing world?, in Law \& Globalisation, Saarbrucken: Bocconi School of Law and VDM Publishing

Mares, R. (2012a). The UN Guiding Principles on Business and Human Rights. Brill, Antwerp. 
Mares, R. (2012b). Business and Human Rights After Ruggie: Foundations, the Art of Simplification and the Imperative of Cumulative Progress. In R. Mares (ed.) The UN Guiding Principles on Business and Human Rights, (1-50). Brill, Antwerp.

Mares, R. (2006). Institutionalisation of Corporate Social Responsibilities - Synergies between the Practices of Leading Multinational Enterprises and Human Rights Law/Policy. Faculty of Law, Lund University, Lund.

Matten, D., and Moon, J. (2008). 'Implicit' and 'Explicit' CSR: A conceptual framework for a comparative understanding of corporate social responsibility. Academy of Management Review $33(2), 404-424$

Mayer, A.E. (2009). Human rights as a dimension of CSR: The blurred lines between legal and nonlegal categories. Journal of Business Ethics 88(4), 561-577

McBarnet, D. (2008). Corporate social responsibility beyond law, through law, for law: the new corporate accountability. In D. McBarnet, A. Voiculescu and T. Campbell (eds.) The new corporate accountability: Corporate Social Responsibility and the law, (9-58). Cambridge University Press, Cambridge.

McCorquedale, R. (2009). Corporate Social Responsibility and International Human Rights Law. Journal of Business Ethics 87(2), 385-400.

Jeremy Moon (2004) Government as a Driver of Corporate Social Responsibility, University of Nottingham: International Centre for Corporate Social Responsibility, No. 20-2004 ICCSR Research Paper Series - ISSN 1479-5124

Muchlinski, P. (2012). Implementing the new UN Corporate human rights framework: Implications for corporate law, governance and regulation. Business Ethics Quarterly 22(1), 145-177

Muchlinski, P.T. (2007). Multinational Enterprises and the law. $2^{\text {nd }}$ ed.. Oxford University Press, Oxford.

Nelsen, J.L. (2006). Social Licence to Operate. International Journal of Mining, Reclamation and Environment 20(3),161-162.

OECD (Organisation of Economic Cooperation and Development) (2011). OECD Guidelines for Multinational Enterprises. May 2011, OECD, Paris.

Owen, John R. \& Deanna Kemp (2013) Social licence and mining: A critical perspective, 38 Resources Policy: 29-35

Picciotto, Sol (2011) Regulating global corporate capitalism, Cambridge: Cambridge University Press

Picciotto, Sol (2003) Rights, responsibilities and regulation of international business, Columbia Journal of Transnational Law Vol. 42 No. 1: 131-152 
Porter, M.E. and Kramer, M.R. (2006). Strategy \& Society: The link between competitive advantage and Corporate Social Responsibility. Harvard Business Review: 78-92

Porter, M. and Kramer, M. (2011). Creating Shared Value. Harvard Business Review, January/February 2011.

Prno, Jason \& D. Scott Slocombe (2012) Exploring the origins of 'social license to operate' in the mining sector: Perspectives from governance and sustainability theories, 37 Resources Policy: 346357

Raelin, J. D. and Bondy, K. (2013), Putting the Good Back in Good Corporate Governance: The Presence and Problems of Double-Layered Agency Theory. Corporate Governance: An International Review, 21: 420-435. doi: 10.1111/corg.12038

Rasche, A. (2010). 'A Necessary Supplement': What the United Nations Global Compact (and is not). Business and Society 48(4), 511-537.

Reich, R. B. (2007). Supercapitalism: The transformation of business, democracy and everyday life. Knopf, New York

Risse, Thomas and Mareike Kleine (2010) Deliberation in negotiations, Journal of European Public Policy, Vol. 17, No 5: 708-726.

Ruggie, J.G. (2004). Reconstituting the global public domain - issues, actors and practices. European Journal of International Relations 10(4), 499-531.

Ruggie, J. (2005) Report of the United Nations High Commissioner for Human Rights on the sectoral consultation entitled "Human Rights and the extractive industry

Ruggie, J.G. (2007). Business and human rights: the evolving international agenda. American Journal of International Law 101(4), 819-840

Ruggie, J. (2011). A conversation with John Ruggie. Fletcher Forum, 35(2), 117-122

Ruggie, J. (2013). Just Business. Norton Publishers, Boston.

Scherer, A.G. and Palazzo, G. (2011). The new political role of business in a globalized world: A review of a new perspective on CSR and its implications for the firm, governance and democracy Journal of Management Studies 48(4), 899-931.

Sen, Amartya (2004). Elements of a theory of human rights. Philosophy and public affairs (32(4), 315-56

Shelton, Dinah (2006) International law and 'Relative Normativity', in Evans, Malcolm D. (ed.) International law, $2^{\text {nd }}$ ed., Oxford: Oxford University Press: 159-185 
Smith, T. (2005). Institutional and social investors find common ground. Journal of Investing 14(3), 57-65.

SRSG (2007) Summary report: Latin America consultation: Held by the Special Representative of the Secretary-General on human rights and transnational corporations and other business enterprises, Bogota, January 18 \& 19, 2007

Steurer, R., Margula, S. (2009). Public policies on CSR in Europe: Themes, instruments and regional differences. CORE Conference IV: The potential of CSR to support the integration of core EU strategies, Berlin, June 15-16, 2009.

Strand, R. (2009). Corporate Responsibility in Scandinavian Supply Chains. Journal of Business Ethics 85(1), 179-185.

Teubner, G. (1997). 'Global Bukowina': Legal pluralism in the world society. In Teubner, Gunther (ed.) Global Law without a State, (1-30). Dartmouth, Hants

Teubner, G. (2000). Contracting worlds: The many autonomies of private law. Social and Legal Studies 9(3), 399-417.

Trubek, D. M. (2004). Human Rights, Transnational private law litigation and corporate accountability. In C. Joerges, I-J. Sand \& G. Teubner (eds) Transnational Governance and Constitutionalism, (321-325). Oxford: Hart

UN (2005). Human rights and transnational corporations and other business enterprises, UN Doc. E/CN.4./2005/L.87, 15 April 2005. United Nations, Geneva.

UN (2008). Protect, respect and remedy: A framework for business and human rights. UN Doc. A/HRC/8/5 (2008), 7 April 2008. United Nations, Geneva.

UN (2011). Guiding Principles on Business and Human Rights: Implementing the United Nations 'Protect, Respect, Remedy' Framework, UN Doc. A/HRC/17/31, 21 March 2011. United Nations, Geneva.

Voiculescu, A. (2011). Challenges and innovation in the legal discourse: Achieving corporate responsibility for human rights. Society and Business Review 6(3), 278-291.

Wettstein, F. (2009). Beyond voluntariness, beyond CSR: Making a case for human rights and justice. Business and Society Review 114(1), 125-152.

Whelan, G., Moon, J. and Orlitzky, M. (2009). Human rights, transnational corporations and embedded liberalism: What chance consensus? Journal of Business Ethics 87(3), 367-383.

Wood, S. (2012) The case for leverage-based corporate human rights responsibility. Business Ethics Quarterly 22(1), 63-98.

Zahle, H. (1999). Rettens Kilder [Sources of Law]. Ejlers, Copenhagen. 
Zahle, H. (2006). Forfatningsret [Constitutional Law]. Ejlers, Copenhagen.

Zumbansen, P. (2012) Transnational law, Evolving, In J. Smits (ed.) Elgar Encyclopedia of Comparative Law, $2^{\text {nd }}$ edition, (898-925). Edgar Elgar, Cheltenham. 